内航船船の航行実態調査

一航海計器の装備・運用を中心にして一

和氣 博嗣 $*$ 藤井 英信 ${ }^{*} \cdot$ 林 祐司 $*$

\title{
An Actual Condition Survey of Domestic Shipping -Survey for Navigation Equipments and Their Employment-
}

\author{
Hirotsugu WAKE, Hidenobu FUJII and Yuji HAYASHI
}

\begin{abstract}
The domestic shipping in Japan plays the leading part of the domestic physical distribution making good use of their voluminous and low cost transportation with long distance. On the other hand, it is said that the number of crews and ships of advance age is increasing in Japanese domestic shipping.

We operated the questionnaire survey of the domestic shipping for making clear such situations of the crews and ships, and finding out the improvement points for the future.

1,500 copies of survey sheets were sent by mail to 154 shipping companies including ferry ones, and the survey replied from 392 persons (RCVY 26.1 percent) were obtained in this time. The analysis for this survey was carried out, and the effective results became clear.
\end{abstract}

\section{1.はじめに}

四周を海に囲まれ、エネルギーや工業用原材料、 食糧等多くの資源や材料を海外からの輸入に依存し ている我が国にとって、外航海運の直接的な重要性 はもちろんのこと、内航海運は国内輸送における不 可欠の大動脈としての役割を果たしてきている。

ただ、近年景気低迷が長引いていることによって、 1998年度時点までにおける推移は、輸送量および輸 送活動量（トンキロ）ともに年々の減少傾向が見ら れる。(1)

しかし、自動車、鉄道等、他の国内輸送機関との 比較で見れば、輸送トンキロベースでは自動車によ る翰送が全体の約 $54 \%$ を占めるのに次いで、内航海 運が $41.7 \%$ の貨物を受け持っており、まさしく国内 物流の大動脈としての働きをしているといってよ い。中でも、石油、鉄鋼、セメント等の産業基幹物 資に係る分野に扔いては、内航海運が低コストで長 距離、大量輸送の利点を生かして、その大部分の輸 送を受け持ち、大きな役割を果たしている。(2)
一方において、内航海運は全体的に船体の老朽化 が進み、次代を担う若者にとって魅力に欠けるとと もに乗組員の高齢化も進んでいると言われてい る。(3)

こうした情勢の中で、内航船舶の運航害態がどの ような状態にあるのかを、問題点の有無や将来の展 望も含めて把握すべく各船の乗組員に対してアン ケート調查を実施した。本論ではこれらの結果につ いて、航海計器の運用と航海の実態を中心にして分 析を試み、一応の結果が得られたので報告をする。

\section{2. 調査の概要}

資料(4)によれば、平成11年 3 月末現在の内航海運 事業者数は 5,624 (兼業を除く)にのぼり、隻数では 7,925隻に達する。

様々な要件を総合的に検討した結果、今回の調查 は1,500部（全内航隻数の18.9\%）の調査票を154事 業者（全事業者数の $2.7 \%$ ) に対して、平成 12 年 6 月 9 日に発送し、同年7月末の締め切りで依頼をした。 ただし、今回の調查対象にフェリー等旅客船が含ま

* 正会員 神戸商船大学（广658-0022 神戸市東灘区深江南町5-1-1）

** 正会員 大島商船高等専門学校（干742-2193 山口県大島郡大島町小松1091-1） 


\section{れている。}

回答状況は、8月 4 日現在で392件の回答を得てお ク、その回収率は $26.1 \%$ を゙る。

\section{1 調査の内容}

今回のアンケートによる調查票は、主として航海 学的な見地から、内航各船がどのような条件、どの ような態勢で、装備された航海計器等を如何に利用 しているのかなどの設問を通じて、航海の実態を把 握しようとしたものである。

したがって、調査票の内容はかなり広範な設問と なり、A 4 版紙に大項目で10問、10ページにわたるも のである。アンケートの設問内容は概略以下のとお クである。

(1) 総トン数、速力、航路等

(2) 乗組員の構成

(3) 航海当直の体制

(4) 航海計器等の装備状況と使用状況

（5）航海中の船位確認状況

(6) 避航操船と海難の経験

（7）海図の整備と利用状況

(8) 電子海困の有無と利用状況

（9）回答者に関する項目（職種、年齢、経験等）

(10) 全般に対する自由意見

\section{3. 調査の結果}

全体のアンケートの設問内容は上述のとおりであ るが、調査結果の整理法としては、先ず全体の回答 結果を設問ごとに集計整理した上で、特に回答者の 属性別（年歯命、職種、海技免状等）、船型別（総卜ン 数別)、船齢別等によってレーダをはじめとする航海 計器の使用状況や海図の扱いなどに対する航海の実 施に、何らかの差異が見出せるかどうかを中心に結 果をまとめていくことにする。

\section{1 回答者に関する項目}

今回の調査では、370隻の内航船舶から392人の回 答を得ているが、それらの回答者の属性を表す第一

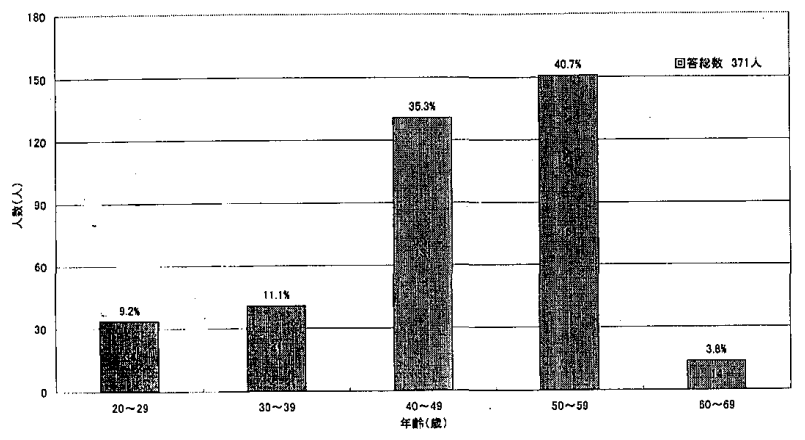

困 1 回答者の年齢

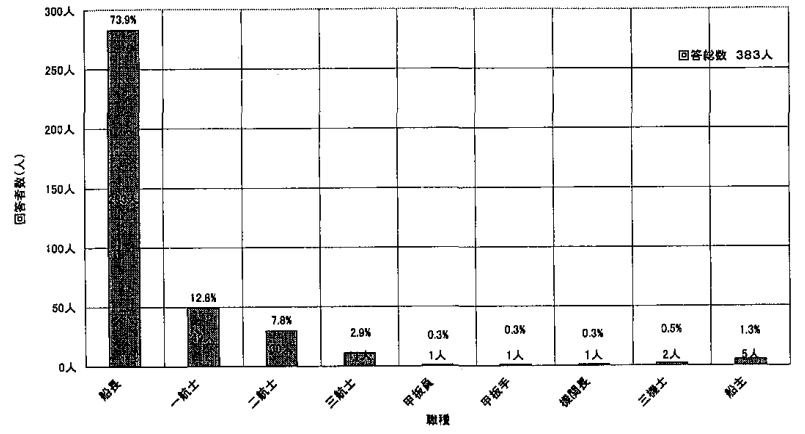

図 2 回答者の職種

の要素として、回答者の年嚙に関してまとめたもの が図 1 である。また同時に回答者の職種についてま とめたものを図 2 に示す。

全体的に見て、年龄的には50歳台が最も多く、50 歳以上の回答者が全体の $44.5 \%$ 占め、残りの55. $5 \%$ 40 歳台以下となっている。一方、図 2 に示すよ うに回答者の職種においては、今回の調査の回答者 の約3／4（73.9\%）が船長からの回答であり、船長 自らの回答が非常に多いのが今回の特徵である。

なお、今回の調査内容の性格上、甲板部に属する 人からの回答が多いのは当然のことといえ、全体の 97.4\%が船長を含む航海士からの回答であった。

また、回答者が保有している海技免状の種類につ いては図 3 に示すとおりであり、三級 $(45.3 \%)$ お よび四級 $(19.9 \%)$ の海技免状保有者が大半を占め ている。困には示していないが、さらに詳細に見れ ば、一級免状保有者 40 名のうち半数の 20 名がフェ リ一の船長であり、次いでセメント船の船長が多い (7 名)。この様な状況は二級の免状保有者において もほぼ同様である。しかしこれに対して、三級と四 級の免状保有者は、各船種にわたってほぼ一様に分 布しているのが特徴的である。

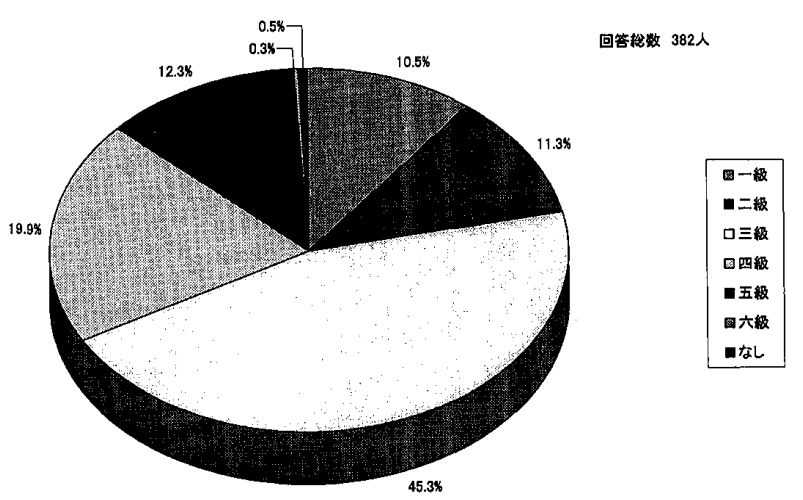

図 3 回答者の保有海技免状 


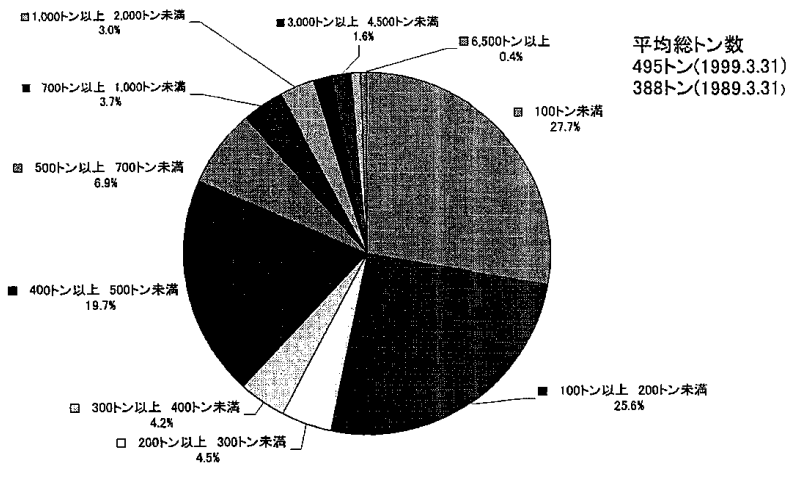

困 4 内航船の船型別船腹量 出所：運輸省海上交通局資料

\section{2 船型別分布と船齢}

内航船舶全体の船腹量を総卜ン数による船型別船 腹量(4)でみると、平成11年 3 月末現在においては図 4 に示すとおりである。総トン数 100 綕トン未满のも のおよび100総卜ン以上 200 総卜ン未满のものがそれ ぞれ全体のほぼ1／4強を占め、次いで 400 総卜ン以上 500 総トン未満の船舶が19.7\%を占めている。

このように、我が国の内航船舶においては、100総 トン未満の船舶の他、いわゆる199総トン型と499総 トン型の船型が標準的なものとなっているのが特徵 であり、全体的には500総トン未満の船舶が圧倒的に 多い $(81.7 \%)$ こを示している。

一方、困 5 は今回の回答結果をまとめたものであ ク、図4に示した内航船舶全体の傾向とやや異なった 分布となっている。この理由はいくつか考之られ、 その一つはアンケートの発送を主として会社単位に 送ったため、個人企業に多い 100 総トン未満の船舶か らの回答が極端に少ないこと、フェリ一等内航の旅 客船も含めたために全体の構成が変わり、特に 5,000 総トン以上クラスは、その大半をフェリーが占めて いることなどによるものである。

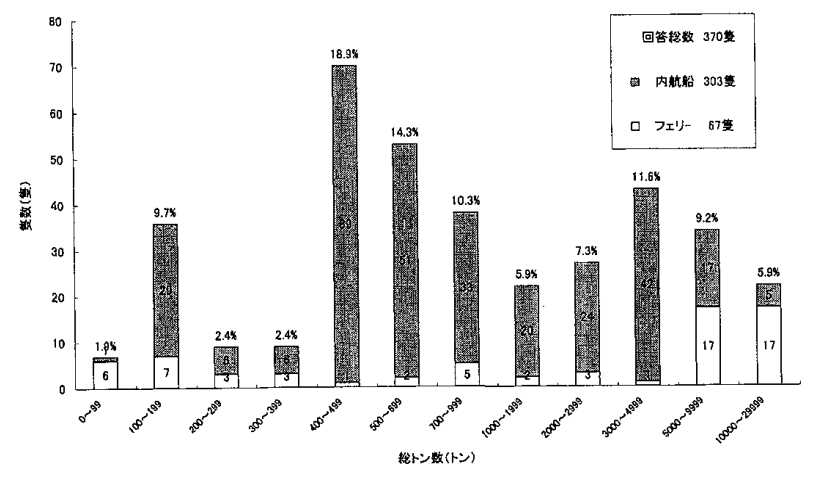

図 5 船型別隻数分布（回答分）
したがって、今回得られた回答の船型別分布にお いても、199総トン型と499総トン型に一応のピーク は見られるものの、全体的には500総卜ン以上の船舶 からの回答が多かった。（回答全体の64.6\%)これは 今回の調査が内航船舶の中でも比較的大型のものに 偏っているといえ、今後は調査方法を含めて、小型 の内航船舶に対する補完を考慮する必要があろう。

罒には表していないが船種について船型別に見る と、鋼材を運ぶ船が 499 総トン型の約 $44 \%$ 占めてお ク、LPG船は500〜900総トンクラスの約30\%、3， 000〜5,000総トンクラスの約半数はセメント船で、 5,000 総卜ン以上の約 $60 \%$ をフリーが占めている のが特徴的である。

船齢については図 6 に示すように、今回の回答分 については 6 １0年あたりに分布のピークがあり、 いわゆる老朽船に属する船齢 16 年以上の船***はあ わせて $13.5 \%$ あるあ。なお、回答分の平均船齢は 10 年であった。

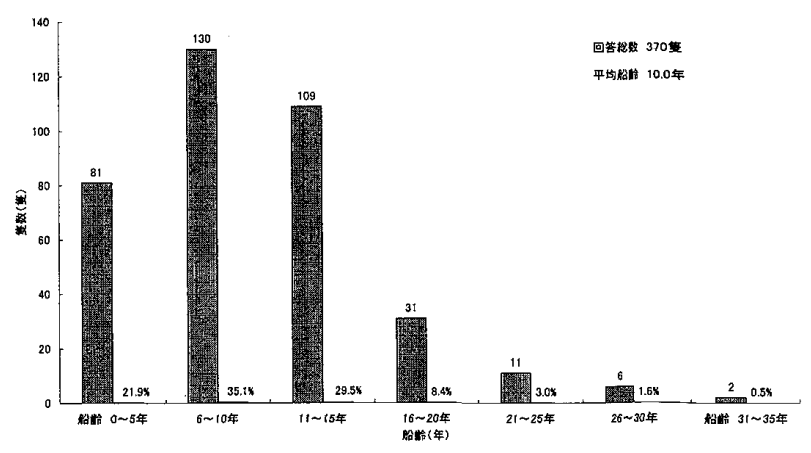

困 6 船㱓分布（回答分）

\section{3 航海計器の装備率}

レーダやコンパスなど船舶に装備される航海計器 をはじめ、スラスターなど操船用の装置も含めて各 船の装備状況を知るために設問した回答結果を図 7

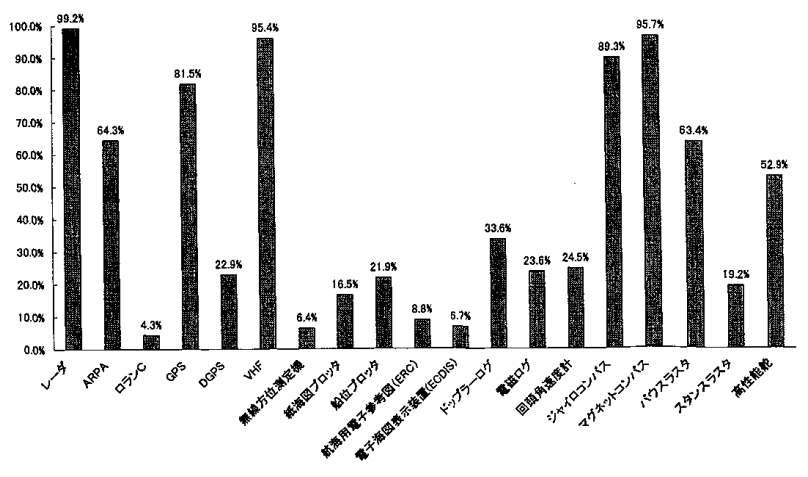

図 7 航海計器の装備率

*** 内航関係の統計資料では、船齢 7 年未満の船舶を経済船、船齢14年以上の船舶を老朽船としている。 
に示す。

レーダやコンパスなど船舶設備規程によって装備 が義務づけられている装置については、それぞれ規 程の要件に合わせて相対的には高い装備率となって いるが、既に十分普及していると思われるレーダや ジャイロ、さらには磁気コンパスに至るまで、100\% の装備には至っていない。

一方、衛星航法装置 (GPS) や衝突予防援助装置 (ARPA) の装備率がかなり高いことや、最近の電 子海図 (ECDIS) そのもののの装備はまだ少ないが、 航海用電子参考図 (ERC) や船位プッロッ夕、紙海 図プロッ夕も含めて、海図上に何らかの形で自船の 船位を自動的に表示する装置を持つ船が、これらを 合わせると約 $54 \% に$ 達することは注目に值する。

\section{4 レーダおよびARPAの使用状況}

代表的な航海計器の使用状況として、ここでは レーダおよびARPAについての回答結果をみてみ よう。

先ずレーダについては、381名の回答者について、 「常時使用している」(59.1\%) が大半で、「通常航 海ではおおむね使用している」が $27.0 \%$ 、「必要な時 だけ使用している」(13.6\%) と続き、狭視界時のみ 使用するのは 1 名 $(0.3 \%)$ であった。

これに対して、ARPAの使用については回答総数 が268名であるが、結果を図8に示している。レーダ の使用状況と比較的類似した結果となっているが、 レーダに比べて「常時使用している」状態から $10 \%$ ほど「おおむね使用している」状態にシフトした形 となっている。残りは「狭視界時のみ使用」を含め て「必要なときだけ使用」(13.4\%) がレーダの使用 状況と重なり合う。

回管粉数 268 人

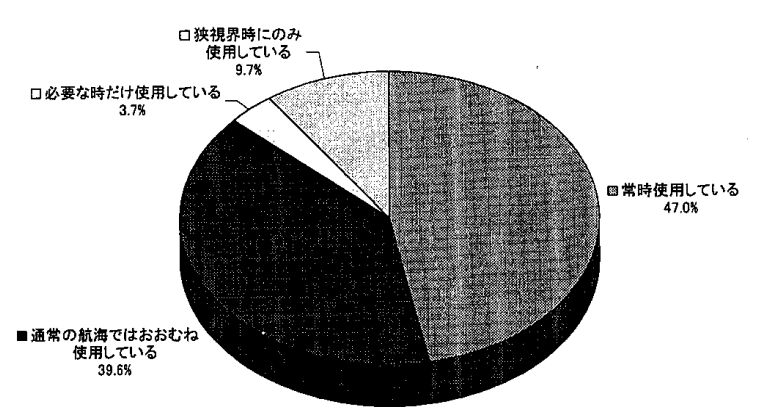

図 8 ARPAの使用状況

\section{5 船位の決定と期待する船位精度}

航海中、停泊中を問わず、自船の船位をより正確 に測定・把握し、常に安全サイドに対処行動をとる ことは航海者の基本である。今回は特に航海中にお

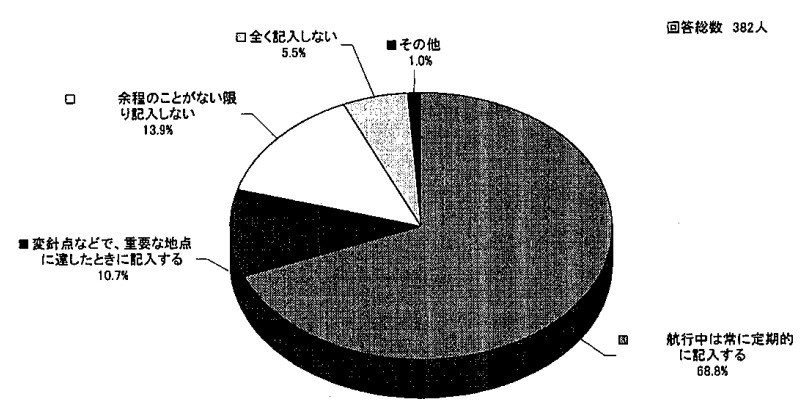

困 9 船位記入の頻度

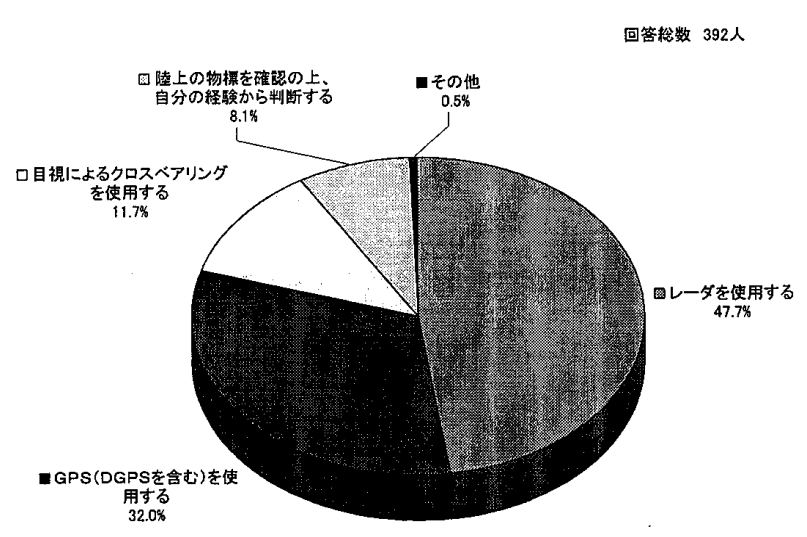

目10＼cjkstart沿岸航行中の船位決定法

いて、海図に船位を記入する状況についての項目を 設け、沿岸航海中の船位決定方法についても調查し た。それらの結果を図 9 と図10に示す。

図 9 によれば、約 8 割の人は「定期的」または「重 要地点」において位置の記入をし確認を実行してい るが、約 2 割の人が「余程のことがない限り記入し ない」か「全く記入しない」と回答している。この 理由について最も多いのが「GPS等により船位の確 認が出来る」 $(40.8 \%)$ 、次いで「航路を熟知してい るため」(28.9\%)、「見張りがおろそかになるため」 (14.5\%) などとなっている。

沿岸航海中の船位決定法については、レーダの使 用が約半数、GPSがほぼ1/3を占め、残り 2 割が目 視または経験によるものとなっている。(図10)

いくつかある船位測定法の中から、ある測位法を 選び船位の決定を行う場合、その測位方法に対する 船位精度の期待值のようなものがあるはずである。 この点に関する設問結果がGPS（図11）およびクロ スベアリング（図12）についてまとめてある。

\section{6 海図の使用状況}

船舶の安全航行を実施する上で、地理情報ならび に一部定性的な潮流の状況まで含めて基本的な航海 情報が最もコンパクトにまとめられているものが海 図であるといえる。これら海図を各船における海図 の利用頻度についての結果を図13に示す。 


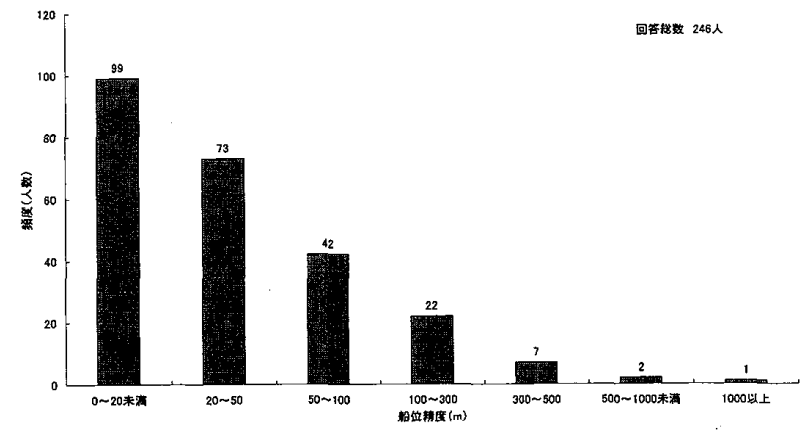

困11 期待している船位精度（GPS）

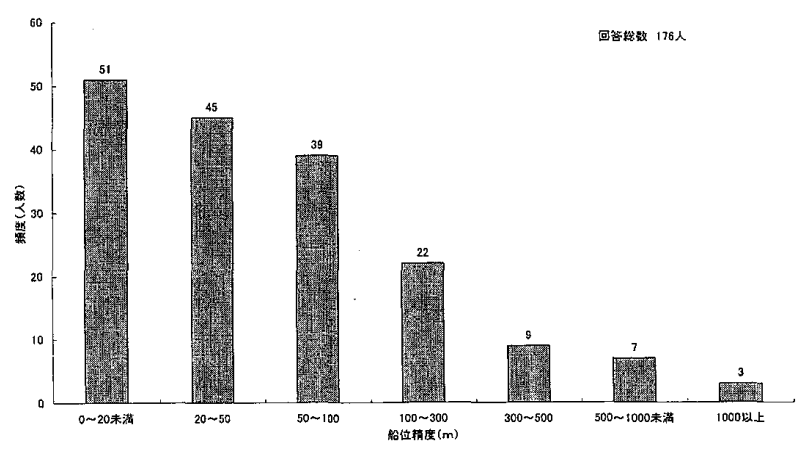

図12 期待している船位精度（クロスベアリング）

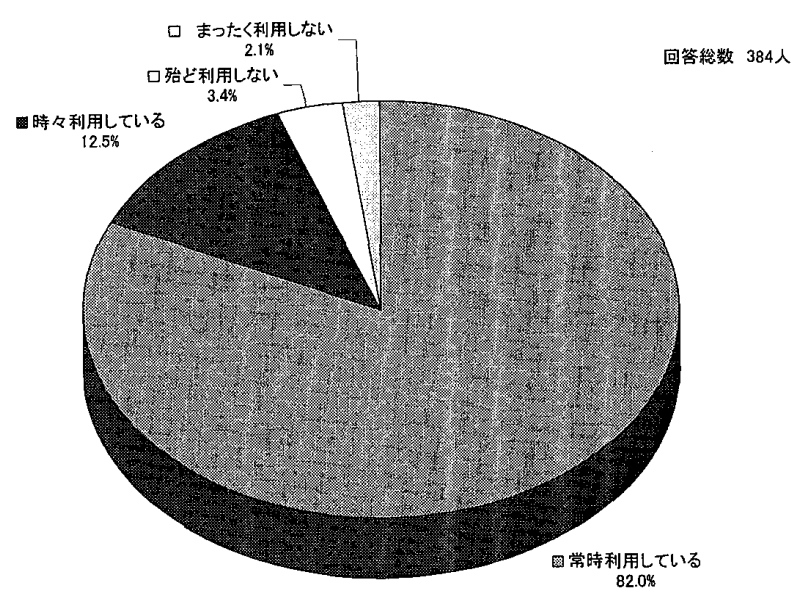

困13 海図の利用頻度

「常時利用している」(82.0\%) に「時々利用して いる」(12.5\%)を加えると約 $95 \%$ のが海図をよく 利用しているといえるが、残り $5 \%$ の人は「ほとん ど」または「全く」利用していない。

また、海図はその情報が刻々と変化するので、適 切な利用を継続するためには水路通報等の入手によ り海図の改補を実行しなければならない。これらの 実施については、大部分の人が「水路通報を入手军 る」(85.5\%) が、14.5\%の人が「いいえ」と答之、 海図改補の実施も「殆ど実施しない」が13.7\%を占 めている。
これらを総合して考えると、通常「殆ど海困を利 用しない」人が約 $5 \%$ お、適正な海図の使用がな されていない場合が全体の約15\%程度はあることを 示している。

\section{7 電子海図について}

電子海図についてはECDISとERCの区別をあ之 てせず、一般に電子海図装置としての設問とした。 設問内容は(1)搭載の有無、(2)紙海図と比較しての利 点と欠点、(3)搭載をしていない場合の理由と(4)搭載 希望の有無などについての回答を得た。

381名の回答者中、電子海図装置を搭載していると 答えた人は 28 名 $(7.3 \%)$ であり、ERCも含め電子海 図の普及はまだこれからという感が強い。

電子海困の利点としては、(1)自船位置の表示が可

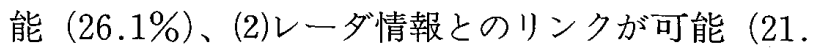
$6 \%$ をあげる人が多く、以下(3)取り扱いが容易 (15. $9 \%) 、(4)$ 航海計画の立案が容易 $(13.6 \%)$ と続いて いる。

反対に電子海図の欠点としては(1)故障時のバック アップがない (31.4\%) とした人が多く、さらに(2) 取り扱いが困難 (20.0\%)、(3)保守に手間がかかる

$(14.3 \%)$ 、画面が見にくい $(14.3 \%)$ などがあげら れている。なお、利点と欠点については、いずれも 28名の複数回答によるものである。

電子海困を搭載していない場合、その理由につい ては353名の回答があり、(1)既存の設備で十分だから (49.4\%)、(2)価格が高いから (23.3\%) が大きな理 由となっており、「性能がよくわからない」(4.3\%)、 「設置場所がない」(4.3\%) および「その他」(20. 2\%)となっている。

搭載していない理由では「既存の設備で十分」が 約半数を占めながら、電子海図の搭載希望を問うた 結果は、「搭載を希望する」が $66.1 \%$ 占め、 $2 / 3$ の 人が電子海困に何らかの興味を示し、将来に向けて 搭載を希望しているものといえよう。

\section{4. 考察}

これまでは各設問に対する回答を単純に取りまと めて整理したものであるが、ここでは回答者の属性

(年龄、職種、海技免状等) と各種航海計器の必要 性との関連性ならびに回答者の考えている精度等に ついて基本的な統計手法を用いて考察を試みた。

\section{1 各種航海計器の必要性との関連}

今回の調査が全内航船舶を対象に無作為に行われ たものとして、回答者の属性と各種航海計器の関連 性を独立性の検定によって調べた。関連性のあるも のについては比率の差の検定を行い母集団間の差を 
表 1 ARPAの必要性

\begin{tabular}{|l|r|r|r|}
\hline & 船長 & 一等航海士以下 & 合計 \\
\hline あり & 124 & 61 & 185 \\
\hline なし & 57 & 7 & 64 \\
\hline 合計 & 181 & 68 & 249 \\
\hline
\end{tabular}

調べた後、母集団の比率を推定した。例えば回答者 の職種（「船長」と「一等航海士以下」）と航海計器 (ARPA）を装備することの必要性についての関連 性は次のようになる。

今回の調查による実測度数は表 1 のようであり、

職種と航海計器の 2 項目間に関連があるかどうかを 次式により検定する。

$$
T=\Sigma \frac{(\text { 実測度数一期待度数 })^{2}}{\text { 期待度数 }}
$$

この結果は、検定統計量 $T=11.631$ (自由度 1 ）と なる。一方 $T$ は自由度 1 の $\chi^{2}$ 分布に従うので、有意 水準を 0.05 に設定して菓却域を求めると 3.841 とな る。この場合 $T \geq \chi^{2}(1,0.05)$ であるので「職種と ARPAの必要性の間に関連がない」という仮説は菓 却され、「2 項目間に関連がある」こととなる。

次に両職種間の母集団の比率が同じであるという 帰無仮説をもとに比率の差の検定を行い、さらに比 率の推定を行った。この結果、比率の差の検定から は「船長」という母集団がARPAを必要とする比率 は「一等航海士以下」より小さいことがわかり、信 頼度95\%（以下同じ）でそれぞれの集団のARPAを 必要とする比率を求めると、船長では（0.617〜0. 753)、一等航海士以下では $(0.825 \sim 0.969)$ となっ た。

同様の手法を用いて各項目について分析した結果 は次のようになる。

(1) ARPAの必要性との関連

・年齢…関連性なし（有意水準 0.05 、以下同じ）

・職種…前述のとおり

・保有免状…関連性あり。「一 二級」のほうが「三 級」より比率は大きい。
（2）GPSの必要性との関連

・年齢 $\cdots$ 関連性なし

・職種…関連性あり。「船長」の方が「一等航海士 以下」よりGPSを必要とする比率が大きい。「船 長」ではGPSを必要とする母集団の比率は（0. 908 0.969)、「一等航海士以下」では $(0.790 \sim 0$. 935）となる。

・保有免状…関連性あり。「一〜三級」の方が「四 〜六級」よりGPSを必要とする比率が大きい が、「四級」と「五〜六級」とは比率の差がある とは言えない。「一〜三級」ではGPSを必要とす る母集団の比率は（0.918０.976）、「四級」で は (0.808〜0.966)、「五一六級」では (0.684〜0. 926）となる。

(3) 船位記入頻度との関連

・年齢…関連性なし

・職種…関連性なし

・保有免状…関連性あり。「一一三級」の方が「四 級以下」より「定期的に船位の確認を行ってい る」と答えた比率が大きい。「一一三級」では母 集団の比率は（0.762 0.859)、「四級以下」で は $(0.340 \sim 0.517)$ となる。

\section{2 回答者が期待する船位精度}

GPS、クロスベアリング及びレーダに対して回答 者が期待している船位精度についての基本統計量を 求めると表 2 のようになる。

さらに母集団の平均值を $95 \%$ の信頼度で推定する と、GPSでは63.1９9.4m、クロスベアリングでは 111.0〜209.9m、レーダでは111.7 141.1mとなっ た。

この結果、精度の母平均の推定值はGPSが最もよ く、次いでレーダ、クロスベアリングの順となった。

\section{5.まとめ}

今回のアンケート調查によって以下のような結果 が得られた。

（1） 1,500部の調查表を内航各社に郵送し、392人 からの回答を得た。回収率は $26.1 \%$ である。

(2) 50 才以上の回答者が $44.5 \% 、 50$ 才満が55.

表 2 期待される位置の精度

\begin{tabular}{|l|r|r|r|r|r|r|r|}
\hline & 回答数 & \multicolumn{1}{|l|}{ 平均值 } & \multicolumn{1}{|l|}{ 中央值 } & \multicolumn{1}{|l|}{ 最小值 } & \multicolumn{1}{l|}{ 最大值 } & 四分位範囲 & 標潐偏差 \\
\hline GPSの精度 & 246 & 81.3 & 50 & 0 & 1200 & 90 & 145.3 \\
\hline $\begin{array}{l}\text { クロスベアリング } \\
\text { の精度 }\end{array}$ & 176 & 160.4 & 50 & 0 & 2000 & 80 & 334.5 \\
\hline レーダの精度 & 284 & 126.4 & 50 & 0 & 3000 & 90 & 280.7 \\
\hline
\end{tabular}


$5 \%$ $\%$ あ、全体の約 $3 / 4$ 船長からの回答であっ た。

（3）保有海技免状に関しては、内航船の性格上三 級または四級の保有者が大半（65\%）を占めてい る。

（4）船型としては199総トン型、499総トン型に一 応のピークはあるが全体的には500総トン以上の 船船からの回答が多かった。(64.6\%)

（5）規程に義務づけられている計器を除けば、 GPSの装備率が高い。

(6)・レーダ及びARPAの使用状況は「常時」また は「拉おむね」使用している人が合わせて $86.1 \%$ に及ぶ。

（7）船位の記入については 2 割の人が殆ど記入し ないと答えているが、その理由として「GPSによ る船位の確認」が最も多く、「航路の熟知」がそれ に次いでいる。

（8）海図の使用については「殆ど利用しない」人 が約 $5 \%$ あり、さらに改補を行わず適切な海図の 使用がなされていない場合が約 $15 \%$ 程度見込まれ る。

（9）現に電子海図を搭載しているのは約 $7 \%$ にす ぎないが、搭載を希望する人が約 $2 / 3$ を占めてい ることがわかった。

(10) 回答者の属性と装備の必要性との関連につい て考察した結果

・ARPAでは「一等航海士以下」が必要とする比 率が大きい。

・GPSでは逆に「船長」の比率が大きかった。

また、保有免状別では

-ARPA、GPSともに上位免状の保有者の方が大 きい比率であった。

なお年橉については両装置とも関連がみられな かった。

(11) 船位を入れる頻度では

・年齢と職種については関連性がみられなかった。 ・保有兔状で上位の比率が大きい結果を得た。

(12) 回答者が期待する船位精度に関してはGPS が最もよく、次いでレーダ、クロスベアリングの 順となった。

\section{6 . あとがき}

最後に、回答者からの自由意見を概略まとめて紹 介し、あとがきに代える。

30件の自由意見が寄せられており、特に多かった ものが、

・若い人が魅力を感じる職場環境の整備、高齢化
が問題とする人が 8 件あり、 そのほか航海計器関係のものとしては、

・計器のハイテク化が進みついていけない

・航海計器の装備に対する行政指導が必要

・電子海四やレーダなどの有用性を述べたもの が各 1 件ずつあった。

\section{謝 辞}

本研究を実施するにあたり、多岐にわたる設問の アンケートに快くご協力いただいた内航海運、フェ リー・旅客船各社ならびに各船の船長はじめ乗組員 の方々に心から感謝の意を表します。また、アンケー トの収集、整理作業については神戸商船大学航海学 コースの西海晴旨学生に多大の協力をいただきまし た。合わせて感謝いたします。

\section{参 考 文 献}

（1） 社)日本船主協会：海運年報1999，1999年.

（2）社日本船主協会：Shipping Now 1999 日本の海 運，1999年.

（3）石谷清幹監修，海上交通システム研究会編：輝 け! 内航海運，1996年.

（4）日本内航海運組合総連合会：内航海運の現況 平成11年度版，平成11年.

\section{質 疑 応 答}

石田廣史 (神戸商船大学)：興味深く調查結果を洋聴 させていただきました。解析を主として海技免状 別になされていましたが、船種・トン数と海技免 状との関係についてお教えください。

和氣博嗣：特に海技免状別のみということではな く、回答者の年歯令別、職種別および回答者が保有 する海技免状別に見て、航海計器等の評価や、航 海に対する対応法に何らかの差異が認められるか どうかに興味の焦点を当てました。

ご質問の今回調査における船種・トン数と海技 免状との関係ですが、論文中の図には表しており ませんが「船型（総トン数）別の船種分布」を見 ますとタンカー、セメント、鋼材、LPG、石死石、 砂利、化学製品等々誠にバラエティーに富んでお ります。しかしその中で499トンには鋼材が多い (44.3\%)、500〜100トンクラスはLPGが約 3 割 を占め、3000～5000トンはセメント（約47\%）、5000 トン以上のクラスの半数以上はフェリー・旅客船 であるなどの特徵が見られます。

なお、船長として必要な海技免状の関係は、船 
舶職員法等（第18条および施行令第 2 条）により 沿海区域及び近海区域に分けて、次のように決 まっています。

総卜ン数 沿海区域 近海区域

200 トン未満 6 級 5 級

200 500トン未満 5 級 4 級

500 1600トン未満 4 級 3 級

1600 卜ン以上 3 級 3 級 $(1,600$

5,000 トン)

1 級 $(5,000$ 卜

ン以上)
堀 晶彦 (海技大学校)：全体の船舶隻数に対して比 率の高い100トン未満の船舶のデータについて、今 回含まれていなかったようですが、今後どのよう にお考えでしょうか。

和氣博嗣：本論文でも説明しておりますように、今 回は会社単位にアンケートをお願いし発送いたし ましたために、個人企業（主として一杯船主が多 い)に多い100総トン未満の船舶からの回答は極端 に少なくなりました。内航船舶の約 $1 / 4 を$ 占める 100総トン未満の船舶を除いて全体を把握したと は言えず、今後の問題としてはこのクラスに焦点 を当てた同様の調査が是非必要だと思います。 